\title{
PELANGGARAN PRINSIP KESANTUNAN BERBAHASA SISWA KELAS VII-B MTs MUHAMMADIYAH 3 YANGGONG DALAM BERKOMUNIKASI DENGAN GURU
}

\author{
VIOLATION OF LANGUAGE POLITENESS PRINCIPLES ON STUDENT-TEACHERS \\ COMMUNICATION AT VII-B MTs MUHAMMADIYAH 3 YANGGONG
}

\author{
Abdul Ghoni Mahmudi ${ }^{*}$, Lulus Irawati ${ }^{2}$, Dwi Rohman Soleh ${ }^{3}$ \\ ${ }^{1,2,3}$ Program Magister Pendidikan Bahasa dan Sastra Indonesia \\ Universitas PGRI Madiun \\ *Corresponding Author: ghoni4657@gmail.com \\ Informasi Artikel:
}

Dikirim: 14/3/2020; Direvisi: 20/5/2020; Diterima: 1/7/2020

\begin{abstract}
This research describes the breach of politeness in learning Indonesian in class VII-B MTs Muhammadiyah 3 Yanggong, Ponorogo Regency. In the Indonesian learning process, especially in the topic "Speaking Indonesian properly and correctly" students should use polite language whenever communicating to the teacher. However, there are still many students who break the principle of politeness. This research used descriptive qualitative method-data collection using the observation method with note-taking and recording techniques. The results of this study indicate that there is a violation of all politeness maxims in learning Indonesian. A form of violating the maxims of wisdom is that students do not respond to their teachers by answering unserious or joking. Flouting of generosity maxims is shown by how students convey their intentions or wishes emotionally. The students violate the maxims of approbation, in which students criticize directly or frankly. Violation of the maxims of modesty is delivered by underestimating the partner. Violation of the agreement's maxims is indicated by students' attitude who do not respect their teacher's orders by speaking in a rude Javanese speech style or ngoko. The students break the maxims of sympathy by boasting or praising themselves in front of their teachers and classmates.
\end{abstract}

Keywords: language, ethics, violations, politeness, ironic.

Abstrak

Penelitian ini bertujuan mendeskripsikan tentang pelanggaran kesantunan berbahasa dalam pembelajaran bahasa Indonesia di kelas VII-B MTs Muhammadiyah 3 Yanggong Kabupaten Ponorogo. Dalam proses pembelajaran bahasa Indonesia, khususnya pada materi "Berbahasa Indonesia yang baik dan benar" siswa selalu diajari untuk menggunakan bahasa yang santun saat berkomunikasi dengan guru. Akan tetapi, dalam kenyataannya masih banyak siswa yang melanggar prinsip kesantunan dalam berkomunikasi dengan gurunya. Metode yang digunakan dalam penelitian ini ialah metode deskriptif-kualitatif. Pengumpulan data dilakukan dengan metode simak dengan teknik catat dan catat. Hasil penelitian ini menunjukkan bahwa dalam proses pembelajaran bahasa Indonesia terjadi pelanggaran pada semua maksim kesantunan berbahasa. Bentuk dari pelanggaran maksim kebijaksanaan ialah siswa tidak menanggapi perintah gurunya dengan sikap yang tidak serius atau bercanda. Pelanggaran maksim 
kedermawanan ditunjukkan dengan cara siswa menyampaikan maksud atau kemauannya secara emosional. Pelanggaran maksim penghargaan yakni siswa menyampaikan mengkritik secara langsung atau terang-terangan. Pelanggaran maksim kerendahan hati dilakukan dengan cara siswa merendahkan mitra tutur. Pelanggaran maksim kesepakatan ditunjukkan dengan sikap siswa yang tidak menghargai perintah gurunya dengan berbicara menggunakan bahasa Jawa ragam ngoko dan dengan diksi yang kasar. Bentuk dari pelanggaran maksim kesimpatian yakni siswa menyombongkan diri atau memuji diri sendiri di hadapan guru dan teman-teman sekelasnya.

Kata kunci: bahasa, etika, pelanggaran, kesantunan, ironis

\section{PENDAHULUAN}

Bahasa merupakan sistem lambang bunyi arbitrer yang digunakan manusia sebagai alat untuk berkomunikasi (Gay, 2018). Secara sederhana, bahasa dapat diartikan sebagai alat atau sarana untuk menyampaikan sesuatu yang terlintas di dalam hati. Secara lebih luas, bahasa merupakan yang dapat digunakan sebagai alat untuk berinteraksi atau alat untuk berkomunikasi, dalam arti alat untuk menyampaikan pikiran, gagasan, konsep atau perasaan.

Dalam setiap komunikasi bahasa ada dua pihak yang terlibat, yaitu pengirim pesan (sender) yang disebut dengan penutur dan penerima pesan (receiver) yang disebut dengan mitra tutur. Setiap manusia diharapkan memiliki kemampuan komunikatif. Kemampuan komunikatif merupakan kemampuan bertutur atau kemampuan untuk menggunakan bahasa sesuai dengan fungsi dan situasi serta norma-norma penggunaan bahasa yang sesuai dengan konteks situasi dan konteks sosial (Fadly, 2017).

Bahasa tidak diperoleh secara serentak dan lengkap, melainkan berkembang secara bertahap sejak masa anak-anak hingga dewasa. Oleh karena itu, bahasa yang digunakan oleh seseorang menunjukkan karakter, watak, atau kepribadian orang tersebut. Karakter, watak, atau kepribadian seseorang dapat dilihat dari perkataan yang diucapkan. Penggunaan bahasa yang lemah lembut, sopan santun, teratur, jelas dan lugas yang mencerminkan bahwa pribadi penuturnya berbudi pekerti baik. Sebaliknya, saat seseorang memaki, memfitnah, membentak, mengejek atau melecehkan akan mencitrakan pribadi yang tidak berbudi pekerti yang baik.

Komunikasi antara penutur dan mitra tutur dikatakan baik apabila maksud dan tujuan dapat dipahami dengan baik oleh mitra tutur (Yustina dan Jumadi, 2015). Jadi, dalam menyampaikan gagasan atau pesan kepada orang lain, harus dituturkan dengan baik dan santun. Selain itu, untuk menjalin hubungan yang baik antara penutur dan mitra tutur harus tercipta perasaan saling menghargai dan menghormati sehingga dalam proses komunikasi dapat tercipta suasana nyaman dan santun.

Kesantunan merupakan fenomena yang umum dalam penggunaan kegiatan berbahasa. Prinsip kesantunan dalam bahasa Indonesia telah mewarnai berbagai aktivitas berbahasa manusia, baik dalam bahasa lisan maupun tulisan (Musyawir, 2019). Pada penggunaan bahasa secara langsung atau lisan akan terjadi sebuah tuturan antar individu maupun kelompok. Tuturan tersebut mengakibatkan terciptanya peristiwa tutur. Peristiwa tutur adalah kegiatan berlangsungnya interaksi kebahasaan dalam satu bentuk tuturan atau beberapa tuturan yang melibatkan dua pihak, yaitu penutur dan mitra tutur, dengan sebuah pokok tuturan didalam waktu, tempat, dan situasi tertentu. 
Pada kajian pragmatik terdapat prinsip-prinsip tentang bagaimana seorang manusia bertutur secara benar, baik, dan santun. Prinsip-prinsip tersebut adalah prinsip kesopanan atau kesantunan Leech (1993). Leech (1993) dalam teori kesantunan berbahasanya membagi prinsip kesantunan menjadi enam, yakni: (1) maksim kebijaksanaan, (2) maksim kedermawanan, (3) maksim penghargaan, (4) maksim kerendahan hati, (5) maksim pemufakatan, dan (6) maksim kesimpatian.

Bahasa Indonesia telah berkembang pesat sejak dikukuhkan sebagai bahasa persatuan Negara republic Indonesia pada 28 Oktober 1928 hingga sekarang. Dalam perkembangannya, bahasa Indonesia juga telah dijadikan sebagai alat komunikasi yang baik bagi masyarakat Indonesia (Asteria, 2016). Sejalan dengan pendapat tersebut Fatimah dan Sari (2018), mengungkapkan bahwa dalam kegiatan berbahasa, ada empat keterampilan berbahasa yang perlu dimiliki oleh semua orang, yaitu menyimak, berbicara, dan berpendapat. Apabila keterampilan berbahasa tersebut telah dimiliki seserang, maka telah baik pula bahasa yang dimiliki.

Sekolah merupakan tempat yang tepat untuk mengajarkan prinsip-prinsip kesantunan berbahasa. Sebab, di sekolah terdapat seperangkat aturan yang mengharuskan siswa menggunakan bahasa yang santun, khususnya kepada guru. Akan tetapi, apabila dilihat dan dicermati dengan seksama, tuturan siswa kepada guru kerap melanggar prinsip kesantunan berbahasa. Hal tersebut dapat dilihat dari cara siswa bertutur kepada guru yang tidak memperhatikan penggunaan bahasa yang tepat kepada orang yang lebih tua dan pantas untuk dihormati. Banyak siswa yang menggunakan tuturan santai, bahkan cenderung kasar saat berkomunikasi dengan guru. Pada saat berkomunikasi dengan guru, baik di luar kelas maupun saat pembelajaran berlangsung, mereka sering menggunakan cara bertutur seperti berkomunikasi dengan sesama temannya. Menurut (Putri dkk., 2019) prinsip kesantunan berbahasa sering kali dilanggar siswa saat dia membawa kebiasaan dari luar ke dalam lingkungan sekolah.

Menurut Munadlir (2016), bangsa Indonesia merupakan bangsa yang multikultural, tetapi bisa hidup berdampingan, saling menghormati, saling mengahargai, saling toleransi, dan bisa berkomunikasi secara santun. Adanya norma kesatunan berbahasa dimaksudkan agar manusia dapat menggunakan bahasa secara santun dalam kehidupan sehari-hari.

Proses penanaman dan cara menggunakan bahasa yang baik dan benar sebenarnya telah dilakukan saat pembelajaran bahasa Indonesia di MTs Muhammadiyah 3 Yanggong Kabupaten Ponorogo. Dalam pembelajaran "bahasa yang baik dan benar" ditekankan aspek kesantunan dalam berbahasa. Seorang siswa selalu diajari untuk menggunakan bahasa yang santun saat berkomunikasi dengan guru (Rahmiati, 2017). Hal ini dilakukan agar siswa di kemudian hari dapat berkomunikasi dengan orang lain dengan cara yang santun ketika berada di tengah masyarakat.

Harapan tersebut ternyata sulit terwujud. Bahkan, ketika berkomunikasi dengan guru pada proses pembelajaran seorang siswa melanggar prinsip kesantunan berbahasa, yaitu pada cara siswa (Meikel) dalam menanggapi perintah dari guru "Nggak mau, Pak. Capek. Di PR saja, kan Cuma segitu". Meikel menjawab dengan angkuh saat diperintah oleh guru untuk mengerjakan tugas setelah materi pelajaran selesai dikerjakan. Pernyataan angkuh dan 
cenderung merendahkan gurunya dituturkan oleh Meikel. Dengan tuturan tersebut dapat dikatakan bahwa Meikel mengambil keuntungan berupa mengunggulkan dirinya di hadapan guru dan teman-temannya. Meikel mengurangi keuntungan gurunya dan menambah keuntungan untuk dirinya sendiri. Tuturan Meikel tersebut apabila dianalisis menggunakan teori kesantunan berbahasa dari Leech (1993) dikategorikan melanggar maksim kesantunan, khususnya maksim kebijaksanaan. Sehubungan dengan hal tersebut, kajian terhadap pelanggaran prinsip kesantunan berbahasa pada pembelajaran bahasa Indonesia di kelas VII-B MTs Muhammadiyah 3 Yanggong Kabupaten Ponorogo.

Berdasarkan latar belakang tersebut, tujuan penelitian ini yakni menghasilkan deskripsi tentang pelanggaran prinsip kesantunan Leech (1993) dalam pembelajaran bahasa Indonesia kelas VIIB MTs Muhammadiyah 3 Yanggong Kabupaten Ponorogo mencakup pelanggaran maksim kearifan, pelanggaran maksim kedermawanan, pelanggaran maksim pujian, pelanggaran maksim kerendahan hati, pelanggaran maksim kesepakatan, dan pelanggaran maksim kesimpatian.

\section{METODE}

Penelitian ini merupakan penelitian deskriptif kualitatif. Menurut Bodgan dan Taylor (dalam Moleong, 2000:4), prosedur penelitian yang dapat menghasilkan data deskriptif berupa kata-kata tertulis maupun tuturan lisan dari orang-orang dan perilaku atau tindakan yang dapat diamati merupakan penelitian kualitatif. Data dalam penelitian ini dikumpulkan dengan cara mencatat tuturan siswa saat berkomunikasi dengan guru pada proses pembelajaran di kelas. Sumber data penelitian ini adalah tuturan siswa saat berkomunikasi dengan guru pada pembelajaran bahasa Indonesia di MTs Muhammadiyah 3 Yanggong Kabupaten Ponorogo.

Data penelitian ini adalah tuturan siswa yang mengandung pelanggaran prinsip kesantunan dalam interaksi pembelajaran bahasa Indonesia. Metode pengumpulan data yang digunakan dalam penelitian ini adalah teknik rekam dan teknik catat. Teknik rekam dilakukan dengan cara merekam tanpa sepengetahuan siswa selama proses pembelajaran. Teknik catat dilakukan untuk mencatat data berupa tuturan yang melanggar maksim kesantunan yang diperoleh dari hasil rekaman pada bulan Januari 2020. Data yang telah terkumpul dianalisis dengan menggunakan teknik deskriptif. Teknik deskriptif merupakan teknik analisis data yang dilakukan dengan cara mendeskripsikan data sesuai dengan rumusan masalah.

\section{HASIL DAN PEMBAHASAN}

Bentuk-bentuk pelanggaran prinsip kesantunan berbahasa siswa dalam berkomunikasi dengan guru dalam pembelajaran bahasa Indonesia di kelas VIIB MTs Muhammadiyah 3 Yanggong Kabupaten Ponorogo adalah sebagai berikut.

\section{Pelanggaran Maksim Kebijkasanaan}

Pelanggaran maksim kebijaksanaan terdapat pada tuturan Bayu saat ditanya guru tentang alasannya tidak masuk sekolah tanpa memberi keterangan. Bayu tidak menjawab 
alasannya dengan jelas yang membuat guru merasa tidak diuntungkan oleh jawaban Bayu. Seperti pada data (1) berikut.

$\begin{array}{ll}\text { Guru } & \text { : Kenapa nggak masuk? Dan nggak ada keterangan? } \\ \text { Bayu } & \text { : Anu pak... } \\ \text { Guru } & \begin{array}{l}\text { : Lain kali kalau tidak masuk, kasih keterangan ya, biar raport kamu } \\ \text { nggak banyak A- nya. }\end{array} \\ \text { Konteks } & : \text { Bayu tidak menjawab dengan jujur terhadap pertanyaan guru. }\end{array}$

Bayu melanggar prinsip kesantunan berbahasa maksim kebijaksanaan dengan menjawab "Anu pak...”. Pernyataan itu diungkapkannnya untuk memberi keuntungan pada dirinya dan mengurangi keuntungan guru. Ketidakjujurannya karena telah membolos, bertujuan untuk mencari sebuah pembenaran atas kesalahannya. Hal itu melanggar prinsip kebijaksanaan karena seharusnya Bayu bisa menyampaikan alasan dengan jujur, sehingga guru tidak perlu mencecar dengan pertanyaan-pertanyaan lain. Dalam penelitian (Febriasari, 2018) dinyatakan bahwa pelanggaran maksim kebijaksanaan terjadi manakala penutur tidak merespon jawaban mitra tutur dengan jujur. Sebab, ketidakjujuran merupakan perilaku menambah keuntungan untuk diri sendiri.

Pelanggaran maksim kebijaksanaan berikutnya terdapat pada tuturan Rafika yang menjawab pernyataan guru mengenai bagian yang ditulis. Rafika berusaha menolak tugas yang diberikan guru. Rafika menggerutu saat pertanyaannya dijawab oleh guru karena merasa itu merupakan tugas yang berat baginya. Seperti pada data (2) berikut.

Rafika : Berarti ditulis semua?

Guru : Iya, soalnya kalau hanya sebagian nanti cerita fantasinya menjadi tidak utuh.

Rafika : Tapi kesel lo Pak. (Tapi lelah lo Pak)

Tuturan Rafika tersebut melanggar prinsip kesantunan berbahasa maksim kebijaksanaan. Pelanggaran itu ditunjukkan dari jawaban Rafika "Tapi kesel lo pak". Seharusnya dia tidak mengatakan itu, dia cukup melaksanakan apa yang dikatakan oleh guru. Rafika tidak memberi keuntungan kepada guru sebagai orang yang seharusnya sangat dihormatinya.

\section{Pelanggaran Maksim Kedermawanan}

Pelanggaran maksim kedermawanan terdapat pada tuturan Rafika saat meminta hasil tugas yang telah dikumpulkan kepada guru. Saat guru membagikan secara berurutan, Rafika meminta dengan nada keras karena dia tidak sabar menunggu gilirannya dipanggil. Bahkan Rafika menggunakan bahasa Jawa ragam ngoko. Seharusnya seorang siswa kalau bertutur dalam bahasa Jawa kepada gurunya menggunakan ragam kromo. Seperti pada data (3) berikut.

Rafika : Aku endi to Pak... Suwineram! (Aku mana to Pak... Lama banget!)

Guru : Sabar Rafika, ini gantian. 
Tuturan Rafika melanggar maksim kedermawanan. Hal tersebut terlihat pada ucapan Rafika yang tidak menghormati gurunya dengan menggunakan bahasa Jawa ngoko dan disertai dengan bentakan atau nada tinggi. Padahal saat itu guru memanggil satu persatu urut berdasarkan absensi. Dalam konteks kesantunan, hal itu tidak sepantasnya diucapkan seorang siswa terhadap guru. Maksim kedermawanan mengharuskan penutur untuk tidak memaksakan kehendak ketika menyampaikan tuturan kepada mitra tutur, tetapi dalam peristiwa tutur di atas, Rafika terlihat memaksakan kehendaknya kepada guru.

Pelanggaran maksim kedermawanan juga terdapat pada tuturan Bayu saat menjawab perintah Guru ketika diingatkan kalau bajunya yang belakang keluar. Saat itu Bayu tidak berterima kasih, justru menjawab kalau bajunya keluar sendiri. Seperti pada data (4) berikut.

Guru : Bajumu yang belakang keluar itu lo. Ayo dimasukkan!

Bayu : La keluar sendiri lo pak.

Pada contoh tuturan di atas, Bayu telah melanggar maksim kedermawanan dalam penyampaian tuturannya. Seharusnya ia meminimalkan ucapannya yang hanya mencari-cari alasan terhadap guru. Akan tetapi, Bayu justru mencari pembenaran dengan sengaja mencari alasan. Seharusnya Bayu segera memasukkan bajunya karena telah diingatkan oleh guru.

\section{Pelanggaran Maksim Penghargaan}

Pelanggaran maksim penghargaan terdapat pada tuturan Ike saat merespon perintah dari guru untuk bekerja sama dengan kelompoknya. Ike tidak menanggapi peritah guru dengan baik. Ike bahkan menolak perintah guru dan dengan sikap yang tidak menghargai gurunya. Seperti pada data (5) berikut.

Guru : Ayo semua kerja sama dengan anggota kelompok masing-masing.

Nia : Iya pak.

Ike : Emoh, Pak!

Nia gak mikir.

Ike telah melanggar maksim penghargaan dalam penyampaian tuturannya. Seharusnya mengikuti perintah gurunya dan meminimalkan kecaman terhadap teman sekelompoknya. Ike membantah perintah guru dan mengatakan kekurangan teman sekelompoknya. Tuturan tersebut cenderung menjelekkan teman yang seharusnya diajak bekerja sama. Dalam maksim penghargaan, penutur diharuskan menghargai pernyataan orang lain.

Pelanggaran maksim penghargaan juga terjadi pada tuturan Nasir yang menyela tuturan gurunya. Ketika guru bertanya alasan kedua siswa yang pada hari sebelumnya tidak masuk sekolah tanpa izin, tiba-tiba Nasir menyela sambil mengejek sebelum kedua siswa yang pada hari sebelumnya tidak masuk sekolah menjawab pertanyaan gurunya. Padahal, guru tidak menanyakan hal tersebut kepada Nasir. Seperti pada data (6) berikut.

Guru : Siapa yang kemarin tidak izin ya? 
Pelanggaran Prinsip Kesantunan Berbahasa Siswa Kelas VII-B MTs Muhammadiyah 3 Yanggong dalam Berkomunikasi dengan Guru (Abdul Ghoni Mahmudi, Lulus Irawati, Dwi Rohman Soleh)

Siswa : (Dua siswa angkat tangan)

Guru : Kenapa kok tidak membuat surat izin?

Nasir : Gak duwe kertas.... Gak duwe amplop! (Tidak punya kertas... Tidak punya amplop)

Nasir telah melanggar maksim penghargaan dengan tuturan yang merendahkan dan memojokkan kedua temannya di depan guru dan teman sekelasnya. Nasir melanggar maksim penghargaan karena berusaha merebut keuntungan dari orang lain. Dia tidak menghargai orang lain yang akan berbicara. Bahkan Nasir justru mengejeknya. Dalam penelitian (Malutin, 2018) dikatakan bahwa penutur yang tidak memberi apresiasi terhadap mitra tuturnya termasuk melanggar maksim penghargaan.

\section{Pelanggaran Maksim Kerendahan Hati}

Pelanggaran maksim kerendahan hati terdapat pada tuturan Sando yang menjawab perintah dari guru dengan tuturan yang congkak. Sando tidak menunjukkan sikap kerendahhatian karena saat bertutur juga sambil melemparkan buku kepada temannya. Dalam prinsip kesantunan berbahasa, penutur yang bertutur dengan sombong atau congkak dikatakan melanggar maksim kerendahan hati atau kesederhanaan (Dari dkk., 2017). Seperti pada data (7) berikut.

Guru : Karena kalian kerja kelompok, silakan yang sudah menulis jawaban duluan,

temannya dikasih tahu! Kecuali kalau tugasnya individu, jawabannya jangan dikasihkan kepada temannya.

Sando : Iki lho! (sambil melemparkan buku kepada temannya) (Ini lho)

Tuturan tersebut melanggar maksim kerendahan hati karena dituturkan dengan keras. Sando terlihat sombong saat ia memberikan jawabannya dengan cara melemparkan buku ke temannya. Tuturan Sando tersebut dikategorikan melanggar maksim kerendahan hati karena dia tidak menunjukkan sikap rendah hati dalam menanggapi pernyataan guru.

Pelanggaran maksim kerendahan hati juga terjadi pada tuturan Tia saat menanggapi pertanyaan dari guru. Dalam tuturan tersebut Tia menjawab pertanyaan guru sambil memotong pembicaraan sambil memberi tahu Ninda (temannya) bahwa tugas yang ada di buku sudah dikerjakannya. Seperti pada data (8) berikut.

Guru : Tugas kelompoknya sudah dikerjakan yang bagian B?

Ninda : Belum selesai pak.

Tia : Uwis tak jawab. (Sudah saya jawab)

Tuturan tersebut telah melanggar maksim kerendahan hati karena Tia menyombongkan diri dengan mengatakan bahwa tugas yang ada dalam buku tersebut telah selesai dikerjakannya. Dia memberikan kerugian kepada Ninda di hadapan gurunya. Tuturan Tia tersebut membuat Ninda menjadi seperti anak yang lebih malas daripada dirinya. 


\section{Pelanggaran Maksim Pemufakatan}

Pelanggaran maksim pemufakatan terlihat pada tuturan Rafika yang tidak dapat menerima tuturan guru saat disampaikan bahwa waktu hampir habis dan tugas harus segera dikumpulkan. Rafika menngerutu karena dia belum selesai mengerjakan tugasnya. Seperti pada data (9) berikut.

Guru : Tugas silakan segera dikumpulkan, karena waktu hampir habis!

Rafika : Yo to.... Sik urung sampe nyatet barang. (Iya kan...masih belum selesai mencatat lagi)

Guru : Kan tadi bapak sudah memberikan waktu yang cukup, tetapi kamu tidak segera mengerjakan.

Dalam data tersebut terlihat kalau Rafika menggerutu karena terjadi ketidakcocokan antara dia dan gurunya. Seharusnya ketidakcocokan tersebut disampaikan dengan baik sehingga ia tidak terkesan memberontak. Dalam maksim pemufakatan penutur dituntut untuk memaksimalkan kesepakatan dengan mitra tutur, tetapi itu tidak dilakukan oleh Rafika.

Pelanggaran maksim pemufakatan juga terjadi pada tuturan Tia yang menjawab pertanyaan dari gurunya. Jawaban yang disampaikan Tia menunjukkan sikap ketidaksepakatan dengan tuturan gurunya. Tia menyuruh guru untuk mengalihkan pertanyaannya kepada kelompok lain. Seperti pada data (10) berikut.

Guru : Kelompok yang lain bagaimana? Semuanya sama? Atau belum? Bagaimana? Tia bagaimana?

Tia : Belum Pak. Mbok yang lain!

Data tuturan tersebut dipandang sebagai bentuk tuturan yang tidak santun karena meminimalkan kesepakatan antara guru dan siswa. Seharusnya walaupun Tia belum selesai mengerjakan tugasnya, ia tidak menyuruh guru untuk menunjuk siswa yang lain untuk menjawab pertanyaan.

\section{Pelanggaran Maksim Kesimpatian}

Pelanggaran maksim kesimpatian terdapat pada tuturan Keysa yang menyela pernyataan guru dengan menggerutu. Saat itu guru meminta siswa untuk tidak keluar dulu sebelum guru menutup pelajaran. Seperti pada data (11) berikut.

Guru : Jangan keluar dulu sebelum saya salam!

Keysa : Boh..Selak luwe lo pak. (Boh...Keburu lapar lo pak)

Tuturan Keysa tersebut melanggar prinsip kesantunan berbahasa maksim kesimpatian. Pelanggaran tersebut terlihat saat Keysa membantah peringatan guru yang mengingatkan untuk tidak keluar sebelum guru mengucapkan salam. Keysa tidak bersikap simpati kepada gurunya. Padahal, seharusnya siswa mematuhi perintah gurunya dan bertutur kata yang lembut. 
Pelanggaran maksim kesimpatian juga terdapat pada tuturan Nindi saat meminjam tipe-x kepada Tia. Nindi bertutur dengan berteriak. Ketika diperingatkan oleh gurunya untuk tidak berteriak di dalam kelas, Nindi bukannya merasa bersalah atau minta maaf. Akan tetapi dia justru membantah peringatan guru tersebut dengan berkata kasar. Seperti pada data (11) berikut.

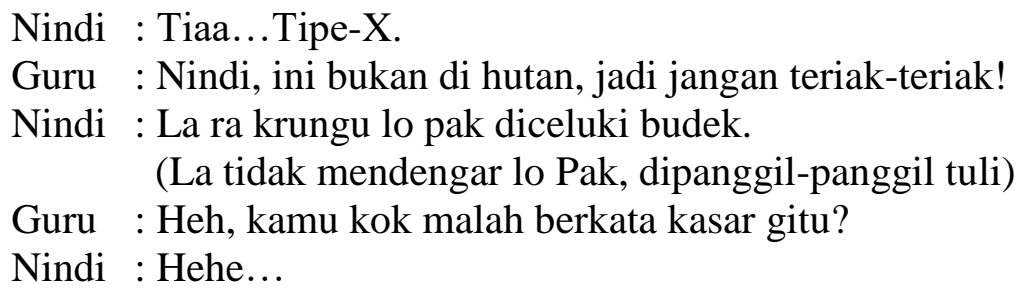

Pelanggaran prinsip kesantunan berbahasa maksim kesimpatian dilakukan oleh Nindi. Dia tidak mengindahkan tuturan guru yang mengingatkan Nindi secara baik-baik. Bahkan ketidaksimpatian Nindi masih berlanjut ketika dia melanjutkan sanggahan atas nasihat guru dengan mengatakan kalau temannya budek yang dalam bahasa Indonesia berarti 'tuli'. Temuan penelitian pelanggaran maksim kesimpatian ini didukung oleh temuan penelitian.

\section{SIMPULAN}

Dalam proses pembelajaran bahasa Indonesia di MTs Muhammadiyah 3 Yanggong Kabupaten Ponorogo, khususnya pada materi tentang cara menggunakan bahasa yang baik dan benar ditekankan aspek kesantunan dalam berbahasa. Siswa selalu diajari untuk menggunakan bahasa yang santun saat berkomunikasi dengan guru. Akan tetapi, dalam kenyataannya masih banyak siswa yang dalam berkomunikasi dengan gurunya tidak mengindahkan nasihat yang disampaikan oleh para guru. Siswa banyak yang melanggar prinsip kesantunan berbahasa dalam berkomunikasi dengan gurunya.

Dari enam prinsip kesantunan berbahasa yang dikemukakan oleh Leech (1993), dalam proses pembelajaran bahasa Indonesia di MTs Muhammadiyah 3 Yanggong Kabupaten Ponorogo, semuanya dilanggar oleh siswa. Keenam maksim kesantunan berbahasa tersebut, antara lain: (1) maksim kebijaksanaan, (2) maksim kedermawanan, (3) maksim penghargaan, (4) maksim kerendahan hati, (5) maksim kesepakatan, dan (6) maksim kesimpatian. Bentuk dari pelanggaran maksim kebijaksanaan ialah siswa tidak menanggapi perintah gurunya dengan sikap yang tidak serius atau bercanda. Pelanggaran maksim kedermawanan ditunjukkan dengan cara siswa menyampaikan maksud atau kemauannya secara emosional. Pelanggaran maksim penghargaan yakni siswa menyampaikan mengkritik secara langsung atau terang-terangan. Pelanggaran maksim kerendahan hati dilakukan dengan cara siswa merendahkan mitra tutur. Pelanggaran maksim kesepakatan ditunjukkan dengan sikap siswa yang tidak menghargai perintah gurunya dengan berbicara menggunakan bahasa Jawa ragam ngoko dan dengan diksi yang kasar. Bentuk dari pelanggaran maksim kesimpatian yakni siswa menyombongkan diri atau memuji diri sendiri di hadapan guru dan teman-teman sekelasnya. 


\section{DAFTAR PUSTAKA}

Asteria, D. 2016. "Optimalisasi Komunikasi Bencana di Media Massa Sebagai Pendukung Manajemen Bencana". Jurnal Komunikasi Ikatan Sarjana Komunikasi Indonesia, 1 (1): $1-11$.

Chaer, A. 2010. Kesantunan Berbahasa. Jakarta: Rineka Cipta.

Dari, A.W., Chandra, D.E., dan Sugiyati, M. S. 2017. "Analisis Kesantunan Berbahasa pada Kegiatan Pembelajaran Kelas VIII E SMPN 2 Kota Bengkulu Tahun Ajaran 2016/2017". Jurnal Ilmiah Korpus, 1 (1).

Fadly, R.W. 2017. "Penggunaan Sarkasme dalam Pergaulan Mahasiswa Universitas Islam Negeri Alauddin Makassar". Skripsi. Makassar: UIN Alauddin Makassar.

Fatimah, dan Sari, R.D.K. 2018. "Strategi Belajar \& Pembelajaran dalam Meningkatkan Keterampilan Bahasa". PENA LITERASI: Jurnal Pendidikan Bahasa dan Sastra Indonesia. 1 (2).

Febriasari, D. 2018. "Kesantunan Berbahasa Dalam Proses Pembelajaran di Sekolah Dasar". Kredo: Jurnal Ilmiah Bahasa dan Sastra. 2 (01):141.

Gay, M. 2018. "Esensi Bahasa dalam Kajian Struktural". Gramatika: Jurnal Ilmiah Kebahasaan dan Kesastraan. 6 (1):49-60.

Jayanti, M., dan Subyantoro, S. 2019. "Pelanggaran Prinsip Kesantunan Berbahasa pada Teks di Media Sosial". Jurnal Sastra Indonesia. 8 (2):118-128.

Leech, G. 1993. Prinsip-Prinsip Pragmatik. Jakarta: Universitas Indonesia.

Malutin, M. 2018. "Tindak Tutur dalam Pembelajaran Bahasa Indonesia Siswa Kelas X di MA Unggulan Al-Kautsar Trowulan Mojokerto Tahun Pelajaran 2015/2016". Matapena: Jurnal Keilmuan Bahasa, Sastra, Dan Pengajarannya. 1 (1):105-120.

Moleong, L.J. 2000. Metode Penelitian Kualitatif. Remaja Rosdakarya; Bandung.

Munadlir, A. 2016. "Strategi Sekolah Dalam Pendidikan Multikultural". Jurnal JPSD (Jurnal Pendidikan Sekolah Dasar). 2 (2):114-130.

Musyawir, M. 2019. "Penyimpangan Prinsip Kesantunan Berbahasa Dalam Interaksi BelajarMengajar Bahasa Indonesia Siswa Kelas XI SMA Negeri 2 Panca Rijang Sidenreng Rappang". Literasi: Jurnal Ilmiah Pendidikan Bahasa, Sastra Indonesia dan Daerah. 4 (02): $1-16$.

Ode, W.N. 2015. "Kesantunan Berbahasa Indonesia Dalam Lingkungan Keluarga (Kajian Sosiopragmatik)". Jurnal Humanika. 15 (3).

Putri, E. C., Suwandi, S., dan Mulyono, S. 2019. "Ekspresi Kesantunan Berbahasa Dalam Pembelajaran Bahasa Indonesia di SMP Muhammadiyah Gatak". Logat: Jurnal Bahasa Indonesia dan Pembelajaran. 7 (2):72-87.

Rahmiati, R. 2017. "Analisis Kesantunan Berbahasa Mahasiswa Uin Alauddin Makassar Dalam Berkomunikasi Dengan Dosen". Al Daulah: Jurnal Hukum Pidana Dan Ketatanegaraan. 6 (1):165-177.

Yustina dan Jumadi. 2015. "Wujud Kesantunan dan Ketidaksantunan Berbahasa Pedagang di Pasar Sentra Antasari Banjarmasin". Jurnal Bahasa, Satra, dan Pembelajarannya (JBSP). 5 (2). 